This is an author generated .pdf for a paper accepted for publication in RELC Journal on November $14^{\text {th }}, 2017$. For the definitive publisher's version, please see RELC Journal, published online at http://journals.sagepub.com/home/rel and in print in the 2018 volume 49, issue 1.

To cite this article:

Rose, Heath \& Montakantiwong, Anuchaya. (2018). A tale of two teachers: A duoethnography of the realistic and idealistic successes and failures of teaching English as an International Language. RELC Journal, 49(1), EPub ahead of print.

\title{
A tale of two teachers: A duoethnography of the realistic and idealistic successes and failures of teaching English as an International Language
}

Heath Rose

The University of Oxford, United Kingdom

Anuchaya Montakantiwong

The University of Oxford, United Kingdom

Mahidol University, Thailand

\begin{abstract}
With the growth of English worldwide there have been numerous calls for a paradigm shift from teaching English as foreign language to teaching English as an international language (EIL). While there is a growing body of conceptual literature for teaching EIL, the voices of teachers remain severely underrepresented in this movement. As such, current EIL research is missing the perspective of this key stakeholder, who is in a prime position to report 'onthe-ground' challenges of integrating EIL approaches into English language classrooms. This paper addresses this gap by offering an in-depth joint autoethnography of two English language teachers, who actively experimented with EIL-informed pedagogy at universities in Japan and Thailand, and who provide very different tales of the resulting challenges and successes. Data was collected via a duoethnographic approach, an innovative methodology which presents two juxtaposing dialogic narratives in order to show readers in-depth, personal and autobiographical accounts from both teachers' experiences. Analysis of these narratives provides an illustration of the issues surrounding the implementation of researchinformed innovations into ELT classrooms. The findings are discussed in terms of whether teaching EIL is a possible reality, or whether it remains ideological fantasy.
\end{abstract}




\section{Introduction}

The increasingly complex reality of today's English usage in international communications has incited numerous calls within the ELT industry for an urgent need to veer away from the native-speaker ideology to a broader view that acknowledges the diverse forms associated with the worldwide expansion of English. Although current calls for change have been framed under different banners, such as teaching EIL (e.g. Marlina, 2018), English as a lingua franca (ELF) aware pedagogy (e.g. Bayyurt \& Sifakis, 2015), Global Englishes language teaching (GELT) (e.g. Galloway \& Rose, 2015), and World Englishes (WE)informed ELT (Matsuda, 2017), they all share similar theoretical assumptions and visions. Many of these calls come from applied linguistics researchers, rather than teaching professionals, and as such a theory practice divide has been observed (Galloway, 2017). While there are a few studies that report on EIL implementation, these have generally focussed on the students' attitudes to WE content (e.g. Galloway \& Rose, 2014; 2017), ELFinformed pedagogy (e.g. Baker, 2012), or ElL-awareness raising (e.g. Rose \& Galloway, 2017). The voices of teachers, in contrast, remain severely under researched. As such, EIL research is missing the perspective of this key stakeholder, who is in a prime position to report 'on-the-ground' challenges of integrating EIL approaches into English language classrooms. This article addresses this gap by offering an in-depth joint autoethnography which embraces our identities as two English language teachers, who actively experimented with EIL pedagogy in our classes in Japan and Thailand, and who provide different tales of the resultant challenges and successes. These experiences are presented in this paper utilizing a duoethnographic approach in order to provide our teacher selves (rather than our researcher selves) with a direct voice.

\section{Background: Is EIL pedagogy a tangible reality or unrealised fantasy?}

A commonality of EIL, ELF, and GELT is their shared calls for reflection on the effectiveness current ELT approaches in terms of whether they are preparing students for current usage of EIL. In global contexts, each speaker engages in negotiation of meaning with other speakers who may come from linguistically and culturally different backgrounds, and thus students need to learn to communicate in such environments. EIL pedagogy requires that greater emphasis be placed on providing students with more exposure to the diversity of English and more practice in using ELF in interactions. EIL places more value on learners' multilingualism, and orients students towards a new mind-set that embraces mutual intelligibility as the ultimate goal in communication instead of native-like competence as defined by so called native-speaker norms (McKay, 2012).

Emboldened by a volume of proposals for a paradigm shift put forward by scholars in applied linguistics, some researcher-practitioners have already embarked on implementing changes in their pedagogical practices. This includes, for example, raising students' awareness of variation in English through a listening journal in Galloway and Rose (2014), in which 108 students in a Japanese university listened to their own selected samples of English varieties, then reflected on this experience in learner journals. Sung (2017) reported on an EILpedagogical activity in Hong Kong, where students were encouraged to participate in ELF communication in a real-world context. A presentation task and debate activity was reported in Galloway and Rose (2017) and Rose and Galloway's (2017), where they observed students' deeper engagement with, and more critical reflections on, a diverse array of English varieties. Vetterol's (2013) action research project explored the efficacy of an ELF interaction exercise between school-aged children in Italy with peers from European countries. Probably the largest studies to date on EIL curriculum implementation are two 
recent research monographs: Galloway's (2017) study of a Global Englishes course at a university in Japan, and Marlina's (2018) study of an EIL program at a university in Australia.

In addition to these few examples of pioneering work in English language classrooms, calls for more classroom-based studies have been answered to some extent in the realm of teacher education. This has been illustrated in a collection of work reported in Matsuda (2017) where EIL ideology and practices were innovatively integrated in pre-service and inservice teacher training programs around the world. Mora and Golovátina-Mora (2017), for instance, managed to set up a master's program in Columbia based entirely on an EIL perspective. Here, in-service teachers were provided with consistent and coherent inputs that enabled them to critically investigate all angles of ELT from the viewpoints of English as an International Language. A more wide-spread model of initial teacher education was presented by Selvi (2017), who described strategic implementation of an undergraduatelevel course called 'Global Englishes' in Northern Cyprus which was a prerequisite to all other ELT courses. This course provided an essential knowledge base of the current status of English as a global language and its implications in the classroom. As noted by Borg (2015), it is during the process of teacher education that the teachers' prior expectations and personally held beliefs are transformed or unchanged by the program agenda-the effect of which can last throughout their entire career. It is therefore worth mentioning that these teacher education programs, though in their early stage and very few in number, are a significant milestone in the attempt to operationalise EIL-based ideology.

Despite continued calls for pedagogically-situated studies, work that reports whether and how these proposed changes continue to make their way into the English language classroom and teacher education remains scarce. Whether the perceived benefits of the EIL-focussed paradigm are brought into pedagogical realities hinges on the very decision the language teachers themselves make. Given that the implications brought about by these decisions have a wide impact on a number of areas from language learning and teaching to language curriculum design, it is surprising, as noted by Young and Walsh (2010: 124), that 'much of the research which has been conducted to date largely ignores what practitioners say, think or believe about varieties of English or about ELF and EIL'. Classroom-based evidence thus far has been mostly limited to studies of learners' attitudes toward EIL content, with the noted exception of Marlina's (2018) study, which also explored EIL educators' perspectives. The scope of inquiry must be expanded to encompass not only the language learners' perceptions of EIL, but also those of the teachers. Multitudinous calls may be made, but unless these calls are adopted by teaching practitioners, the benefits of such change remain unrealised fantasy. In order to demonstrate that EIL proposals are not merely idealistic expectation, reports on how such changes in actual classroom implementation are received by both the students and the teachers themselves need to keep pace.

\section{Methodology: Duoethnography as joint reflective practice}

The current study embodies a duoethnographic research design, by combining two autoethnographies to create a dialogue around central issues of teaching English as an international language. Duoethnographies encourage educators and learners to undertake an autobiographical examination of themselves, using the researcher as the research site. The methodology has similarities to autoethnographies, which 'draw together features of autobiography and ethnography' (Paltridge, 2014: 100). Unlike authoethnographies, however, duoethnographies 'study how two or more individuals give similar and different meanings to a common phenomenon' (Norris, 2017: 2). 
The method of duoethnographies are flexible, and vary from disciplinary norms. As it is an evolving form of inquiry, duoethnographers remain reluctant to dictate precise procedures of inquiry (Breault, 2016). Nevertheless, seminal users of the approach (Norris \& Sawyer, 2012: 12), outline a number of precepts that 'serve as an outline of the types of researcher dispositions, principles, and foci required to undertake this work'. These were later synthesised into four central tenets (Norris, 2017), which are synthesised below:

1. It is dialogic, where the narratives of the researchers are positioned in juxtaposition to each other. It intentionally disrupts the typical nature of metanarratives that can emerge from solitary writing (including collaborative writing synthesised within a single authorial voice)

2. It facilitates reconceptualization of past experiences and stories by allowing the other researcher to challenge the adequacy of the frames held in interpretation. It is not authoritative in stance, but rather positions the reader as an active Other in meaning making, and therefore as an implicit co-author

3. It positions differences as crucial to exploring a larger shared experience. Duoethnographies position differences between the writers' points of view as a strength, and an opportunity to explore different meanings to a shared phenomenon.

4. The methodology must remain open and flexible, to avoid becoming prescriptive. Duoethnographies do not need to adhere to a set procedure.

There is a dearth of published duoethnographies in social science research in general, and within applied linguistics in particular. Thus, a methodological blueprint of how duoethnographies should be conducted and presented are equally scarce. In fact, our search for duoethnographies on language teaching research within the Web of Science and SCOPUS databases revealed only two papers. The first study, by Lowe \& Kiczkowiak (2016), investigated issues surrounding nativespeakerism via a duoethnography of their professional lives as two English language teachers-one 'native speaker', and one 'non-native speaker'. The duoethnography allowed both researchers to re-examine the frames of their own narratives and challenge the lens via which they viewed previous experiences. In the second study, Adamson and Muller (2017) conducted a 'joint autoethnography' to explore the lived experiences of two language teacher-researchers working in higher education in Japan.

With the lack of methodological examples for duoethnography in applied linguistics research, we elected to follow the procedures in these two studies. Both studies were remarkably similar in weaving together two individually produced narratives, that became dialogic via juxtaposed positioning of emergent themes for discussion. Our duoethnography was produced first via the construction of two personal narratives. Upon completion, we each sent our narratives to the other, and made comments on our stories, asked questioned, and challenged some perceptions. Based on this feedback, we reflected on our experiences, adding the interpretations of the other, before finally dissecting these narratives into juxtaposed themes for presentation and discussion. Our duoethnography may be seen as more conservative in approach than examples outside of applied linguistics (e.g. Norris and Sawyer, 2012), where data are presented as a dialogue, and embrace a 'scrapbooking' approach of mixing transcribed conversations and external materials. Likewise, we were more conservative in our personal narratives compared to literary-style autoethnographies (e.g. Ellis \& Bochner 2000), which can include fictional-style writing, poetry and prose. Because duoethnographies should be accessible and of interest to both academics and practitioners (Beault, 2016), we present our ethnographies as excerpts organised within themes of analysis, which are not dissimilar to typical qualitative data presentation, while still allowing for our teacher voices to be transparent. 


\section{Findings: A tale of two teachers}

In the tradition of duoethnographic research, our investigation centres on both authors, using our teacher selves as the research site via dialogic introspection. The investigation explores the lived experiences of one author (Heath) reflecting on his practices of teaching EIL at a university in Japan throughout the years 2008 to 2012. Against this backdrop, the other author Anuchaya (Anya) explores her experiences teaching EIL in 2015 and 2016 at a university in Thailand.

\section{Theme 1: Motivations to teach EIL}

The first theme extracted from the narratives revolved around each of our motivations for integrating EIL into our classes. Excerpts from the narratives, which were produced by each of our participant teacher-selves, are displayed below, along with explanations of the dialogic discussions that ensued.

HEATH'S TALE: My interest in Global Englishes grew out of pragmatic concerns. I was employed in one of Japan's first bilingual business degree programs, working there as an assistant professor. In this program, students were expected to acquire the business knowledge and English language skills needed for future global employment. Thanks to discussions with colleague of mine at my former university, who was researching the topic of Global Englishes, I had become prescient to the fact that my business students were likely to engage in communication with their Korean, Chinese, and South East Asian counterparts than with Inner Circle speakers. This made me question the relevance of the standard English language curriculum which was in place at my university, and to challenge its native-speaker centrality. While some Standard English was necessary for my students' development in order to meet their academic language needs, I felt the curriculum was not adequately preparing them to use the language as a business lingua franca, so I sought to change this.

ANYA'S TALE: The original spark for my interest in Global Englishes and its pedagogical implications was set off in the spring of 2014, when I undertook my Master's studies in the States on my journey to become an English language teacher. Before my TESOL experience, I, like any student learning English as a foreign language, had always wanted (and told) to 'be good at English,' which usually and unfortunately meant sounding like farang (the native speaker in Thai) on the media in and outside the English classroom. However, having been familiarised to terms and core concepts surrounding EIL via course readings, in-class discussions, and field placement, I had learned more about the changing reality of English language usage and the increasingly irrelevant nature of the native-speaker ideals. These insights not only provided me with a new understanding about the subject matter but also helped me regain my confidence as an English language teacher preparing to teach. Upon my return to Thailand, my earliest professional experience was a university English language lecturer in an English undergraduate degree program, which offers English language classes for both major and non-major students. The types of classes ranged from foundation courses for first-year non-major students to ESP courses targeting English majors in need of more specific, career-oriented skill sets. Having recently been introduced to Global Englishes and EIL, I was eager to incorporate what I had learned into my classrooms. Despite this determination, what actually got realized in class was unfortunately not informed by my pre-established teaching values. I had always thought several of my misconceptions about English language learning had been undone, yet it was not until my transitioning from a student learning how to teach to a teacher who performed the actual teaching in a real-life 
language classroom that I realised this demystification was only on the surface. I was clueless as to how those exciting ideas could materialise in the classrooms. In other words, it was interesting in theories but slightly tricky in implementation.

Here, we describe our motivations for wanting to integrate an EIL perspective into our classes, which were from similar ideological standpoints. Both of us had been enamoured by EIL ideas via others, but this was where our similarities ended. While, Heath rationalised his motivation to introduce EIL as a pedagogical need of his students, Anya's motivation was much more personal. She was motivated by the ideological nature of EIL, which was 'demystified' when she transitioned from a teacher-in-training to a professional teacher. When questioned by Heath, Anya stated that 'EIL seemed to me not just an interesting concept, but a personal/professional philosophy I can hold onto and the means by which my goals as a teacher can be achieved'. Thus, Heath saw EIL as a lens to inform teaching practice, whereas Anya saw EIL as a catalyst for the development of her identity as a teacher.

\section{Theme 2: Experimentation with teaching EIL}

Both of our teacher's narratives then turned to lengthy explanations of initial EIL implementation, forming a second theme for analysis. The narratives focussed on quite different elements of L2 instruction, and resulted in different outcomes, as illustrated in the following excerpts:

HEATH'S TALE: In 2008, I started to instigate small changes in the curriculum. First, I adjusted the marking rubrics across all three courses for written assignments and presentations to place more weight on categories such as 'communication of ideas', 'content' and 'structure', and less weight on categories such as 'grammatical accuracy' which I saw as being assessed according to native-speaker benchmarks. For the listening exercises in my introductory EAP classes, I tried to find businessrelated TED talks by expert L2 English users in order to provide students with realistic role models for their future L2 selves. In 2009, when I had a chance to hire teaching assistants for ESP classes (a job that had usually been taken on by university seniors in the Japanese student body), I advertised the position to the exchange students within the business department, specifically calling for students with experience using English as a business or educational lingua franca. I believed these teaching assistants would provide an opportunity to bring real-life ELF practice into the classroom. This initiative resulted in hiring exchange students from Hong Kong, Singapore, Norway, Denmark, and the UK (while native speakers were not excluded, it was not a hiring criterion). The world didn't fall apart, and students seemed to respond positively to the changes, so this spurred me on to try more radical things in the next academic year.

ANYA'S TALE: In the spring semester of 2015, I was assigned to teach a compulsory course entitled 'Listening and Speaking for Communications' for secondyear nursing students. One of the course objectives was that the students will be able to communicate effectively in various real-life situations by the end of course. In one pronunciation session, the students were asked to listen to a speech model on a textbook audio recording before repeating aloud. The reciting was synchronised except for a few students sitting closer in the front rows whose pronunciation I could pick up better. While I had no difficulty understanding their pronunciation of the words, which were clearly articulated and seemed to be perfectly understood by their classmates, somehow the way certain words were pronounced didn't match the way they were supposed to sound like in my teacher's mind. The urge to correct their pronunciation was so strong and sudden that I remember my eyebrow raising and my mouth blurting out something along the lines of a disapproving 'Ah-aa' or 'what did 
you just say?' Instead of drawing the students' attention to the diversity of English and how it was used as a lingua franca by speakers of different language backgrounds, I saw myself telling the students to 'say it like they [the native English speakers] do.' Instead of embracing mutual intelligibility, all I did was mentally spot the 'Thai-ness' in their accent. In retrospect, I was horrified. While the image of a teacher ideal self to which I have always aspired is one who espouses diversity, possesses multilingual skills, and is capable of understanding and being understood by English speakers of various lingua-cultural backgrounds, that desired self failed to materialise in my practices.

At this point in the narrative, Heath questioned Anya on whether the students' Thai accents would have been unintelligible to speakers of different Englishes, to which Anya replied: 'Reflecting on this thought, it is possible that the target interlocutors I had in mind for the students were not so much international audiences but the so-called native speakers of English', and thus she was disappointed that she had adhered to these norms when providing her spontaneous feedback, stating that, 'The dismay I felt led me to contemplate what I could have otherwise offered to the students, and to my own professional teacher self".

We then reflected on our initial implementations in both of our narratives, where we contemplated what we had learned in our first experiences of teaching EIL, which lead to further curricular changes. In Heath's case, as we will see in the excerpts, this involved 'ramping-up' the EIL content based on initial successes; for Anya, this involved deep personal reflection and a re-assessment of how to best frame EIL.

HEATH'S TALE: In 2010, the colleague that had first inspired me to implement an EIL curriculum took up an assistant professor position in my department, at which time we gave the introductory EAP curriculum a major overhaul. Because this course was students' first introduction to the English program, we thus felt it needed to embody a Global Englishes orientation. We created a new introductory module for the course, called 'English as a Global Language', where students directly explored the growth of English and how it was used around the world. Students still learned the required EAP reading skills, note-taking skills, essay-writing skills, and presentation skills that underpinned the curriculum. What had changed was that instead of reading a generic EAP passage for reading comprehension, we gave them adapted articles based on World Englishes and English as a Lingua Franca literature. Instead of practicing note-taking to generic lectures, they listened to TED-talk presentations such as Patricia Ryan's talk on 'Don't insist on English'. This was our first foray into explicitly teaching students about Global Englishes.

For Anya, reflecting on her own disappointment in activities surrounding her listening activities, she set out to change the listening task that had tripped her up, having at this stage been placed in the position of course coordinator. Instead of the one-way, out-ofcontext listening exercises in the commercial textbook, she created a new activity where students recorded their own recordings role playing people calling into a radio station talk show to seek advice on real or fabricated personal situations. These recordings, which were sent to the teacher, formed the basis of the new listening activities, where they were played to the students for the in-class listening task. Anya explains that the activity was inspired by a popular radio programme called 'Club Friday' in which people call in to tell their stories (mostly about their troubled relationships) and the two hosts, famously known as 'relationship gurus', asked questions and gave those callers some advice. Since the activity was adapted from an already well-known programme, the students found it easy to relate to, 
taking on the role of both caller (in the recordings) and hosts (in offering advice in class). In her narrative, Anya stated the following:

ANYA'S TALE: Treating these recordings as if they were real calls, and using them as listening resources like we would for textbook audio, both the students and I acknowledged the legitimacy of the various English forms displayed in the recordings. The students not only found this activity highly relatable but also felt empowered knowing that there were still those who could (or tried to) listen to what they had to say. This not only personalised their language learning experience in a way that prioritized the local contexts but also sensitized them to the communicative purpose of the English language. Listening and trying to make out what their peers had to say, students became more aware of their own prejudices towards the considered 'funny non-native' accents of their peers as well as their own. These changes may seem minor, but seeing them in action instilled me with hope.

In the dialogic stage of writing, Heath reflected on the potential effects of his own small changes, and asked Anya whether she thought 'even minor changes can affect the way your students view variation in English?'. Anya replied:

ANYA'S TALE: Definitely. Apart from gaining more confidence to speak in class (which has been an eternal struggle faced by every Thai EFL teacher), I noticed that the students seemed less worried about what they should sound like in the eyes of others. This does not mean they gave up the wish to be fluent/proficient English language speakers, but 'communication' seemed to be placed in a higher priority than 'native-like proficiency'. They also became more respectful listeners. When their peers spoke in front of the class, they listened more attentively. However, for these minor changes to work in full effect, I think they must be made explicit. After the activities, I told the students explicitly why I did what I did. Explicitness may not change their long-held attitudes but it can get them thinking about the validity of it. Thus, while the activity may seem to represent a small change in the curriculum, the use of the activity as a catalyst via which to challenge students' ideologies of standard language and local variety legitimacy was the real take-away. Reflecting on this, Heath also drew upon his previous experiences of researching EIL at a different university, where students attitudes were profoundly affected via seemingly small curricular changes, such as: using global Englishes listening journals for an out-of-class learning task (reported in Galloway \& Rose, 2014); introducing a global Englishes presentation task (reported in Galloway \& Rose 2017); and debating standard language ideology (reported in Rose \& Galloway 2017). After reflecting on these experiences, our teacher selves concluded that, while EIL innovation may manifest in minor changes, the opportunistic teacher can use these moments as gateways to raise students' awareness and to challenge the status quo.

\section{Theme 3: Reflective practice on teaching EIL}

A final theme in the narratives included reflection on teaching EIL, by both of us, including an exploration of our own role and identity in this process.

HEATH'S TALE: Students responded positively to the changes, which was evidenced from end-of-course feedback. As a teaching team we felt the course gave students more confidence as global users of the language. We felt reading about World Englishes and ELF made students more explicitly aware of how they were likely to use English in the future, and challenged some of their perceptions about Standard English. We felt that the range of guest speakers we invited, coupled with the hiring of ELF-experienced teaching assistants, provided them with positive role models for their future $L 2$ selves. Furthermore, as we monitored language development through the course both before and after the curriculum changes were 
made, we also noted that the changes had not adversely affected any of the formal language outcomes of the course, which were still pinned to Standard English normed tests, with some evidence suggesting even greater increases year-on-year, speculatively due to increased motivation and confidence. For us, teaching EIL was an unequivocal success.

ANYA'S TALE: Given a successful EIL curriculum is characterised by how well, if at all, those ideas are endorsed in the classroom, my early EIL teaching experience can be described as a story of failure since none of those ideas got realised in the first place. As it turned out, what I originally had in mind (to be as open as possible to the diverse pronunciations each student brought to the classroom) proved to be rather different from what I actually did. In my case, I realised it could have been the lack of self-awareness on my part as a language teacher. Caught up in the whirlwind of busy schedules and administrative duties, many teachers could not afford reflection time for themselves. Their teaching philosophies they had once valued got put in the back of their mind. Hadn't I paused to reflect on my own practice then, I wouldn't have come to that shocking realisation which in turn catapulted myself into much-needed action.

In Heath's further reflections, he emphasised the importance of collegial support in maintaining successful EIL implementation, as well as an open-minded student body, who clearly could visualise their future use of English:

HEATH'S TALE: The success of the program, I feel, was due to a number of factors, which created ideal conditions for EIL innovation. First, we had an EIL-aware team of autonomously working teachers, and we were given full autonomy over the curriculum by our superiors, which allowed change to be flexible. Second, the program existed in an EIL-supportive department. Many of the business professors we worked alongside had first-hand experience the business world, and understood the needs of using English as a business language franca. Third, we taught a dynamic and motivated student body, who were keen to use and apply their language skills to all available situations. We may not have had the same success with a student body that did not have a clear vision for why they needed English for their future.

Anya, in reading Heath's narrative and reflecting on pathways forward in improving the EIL curriculum at her university, focussed on the importance of reflective practice:

ANYA'S TALE: Through a close examination of one's own experiences in learning how to teach and doing the teaching itself, I began to become aware of the subtle nuances within one's belief system concerning language learning experience: that of my learner self and that of myself as a teacher. I found that my own learner self's attachment to so-called 'native-like' proficiency somehow prevented my newly realised teaching philosophy from coming into being.....Beyond teachers engaging in a regular self-reflective practice, I feel that an environment that supports the learning/teaching of EIL also needs to be in place. While individual effort to bring about change in one's classroom is a promising start, it is insufficient. To cultivate a realistic and sustainable EIL learning context with students' best interest in mind, a concrete, collective attempt from both the teachers and those responsible for the program's overall policies must be made regarding the entire curriculum.

Thus, one significant difference between both of our experiences appears to be the collective, EIL-aware context of Heath's university which created a critical mass for change, compared to Anya's isolated experience as a new teacher, in which change was individually pursued.

\section{Discussion: What can we learn from these two tales?}


The first lesson learned from these dual narratives is the importance of teacher education in inspiring ideas and forming the impetus for change. For Anya inspiration came from her formal in-service master's studies, which she describes as having changed her language teacher self and belief system. For Heath, inspiration came from learning about Global Englishes via a colleague, which seemed to spark ideas of how it was relevant to his teaching. For both of us, the timing was also important, with Anya noting that 'when EIL was introduced to me, I already had a clear idea of what I would be doing afterward' (Anya's Tale). Heath also noted in his reflective notes that had his teaching been different at that time (for example if he were teaching IELTS preparation classes, as opposed to business students), he may not have understood the importance of EIL at all. These findings point to the need for continued teacher education programs throughout teachers' professional lives. This not only includes the type of master's level theoretical content in applied linguistics courses as outlined in Marlina (2017), or the teacher-targeted postgraduate training illustrated in Mora and Golovátina-Mora (2017), but also more informal types of professional development that range from school-organised training days, teaching workshops, or staff common-room discussions. As Rose (2017: 180-1) notes, teacher education is merely an 'initial step in disseminating these ideas to future teachers, who may then carry them further afield to international, national or regional teaching conferences, organized staff development workshops or even informal staffroom conversations'.

Another key lesson drawn from these tales is the importance of teachers collaboratively, and having the professional freedom to initiate change. Heath's later successes were, in part, due to the arrival of another colleague who shared the same value system. Put in charge of the EAP courses, together they were able to experiment with EIL-informed curricular change. Similarly, when Anya was placed in a position of course coordinator, she could move past the confines of the commercial textbook, and replace it with a more ElL-oriented listening activity. In the dialogic questioning exercise, Anya stated, that 'as a coordinator, I have (or I feel I have) more freedom and authority to integrate change into the curriculum'. In EIL teacher training research, some teacher trainers (e.g. Zacharias, 2017) have noted that teachers, and especially beginning or student teachers, may feel constrained by a lack of freedom to choose materials and to creatively adapt them for EIL pedagogy. It is pertinent, therefore, if innovation is to come from newly-educated teachers, that senior faculty provide them with the necessary professional freedom to innovate their classrooms. Bayyurt and Sifakis (2017: 11) warn that unassisted innovation requires a 'substantial amount of autonomy and maturity', thus collaboration with other teachers (in groups, or under the mentorship of more experienced teachers) can help in the development of EIL-aware lessons.

A final lesson is the importance of reflective practice in order to cogitate new ideas and nurture innovation. Reflective practice describes teachers' systematic process of problem solving through deliberate reflections on specific pedagogical issues. A sub-type of reflective practice involves reflection-for-action (Van Manen 1991), which entails a teacher's making note of the weaknesses in a lesson and proposing an action to address these problems in future lessons' (Uzum et al. 2014: 5). Anya's tale in particular shows the clear advantages of reflection-for-action, and explicitly points to the vital role that reflection played in her decision to innovate the curriculum. Anya further elaborates:

Not only has this act of self-introspection allowed me to ruminate on what learning English really means to me and how my personal language learning histories can affect my pedagogical philosophies and practices, it has also equipped me with a clearer perspective on different approaches I need to take going forward. 
Recent studies (e.g. Burhan-Horasanlı \& Ortaçtepe 2016) have shown how reflective practice can be utilized to help in-service English language teachers to gain insights into their teaching practices and how collaborative reflective practice in particular can aide teachers in 'jointly constructing new meanings about their practice' (Burhan-Horasanlı \& Ortaçtepe 2016: 380). Such practices might explain why Heath, in his collaborative reflective practices with his EIL-aware colleague, was able to instigate greater curricular changes than Anya was independently.

\section{Conclusion}

Transforming an ideological fantasy into a tangible reality requires a carefully-cultivated environment for rethinking. In order to cultivate EIL, one needs teacher education to provide the seeds of change; autonomy and collaboration to provide suitably fertile grounds within with to sew these seeds; and reflective practice to nurture growth. Although the applied linguistics research community has consistently voiced a growing need for a more EILoriented teaching approach, it is surprising how the very voices of the teachers who are supposed to be the megaphone for that message remain unheard. The present paper aims to amplify these voices, acting as a go-between to wed theory to practice. By choosing a duoethnography to present our ideas, we hope to reclaim the EIL narratives from our researcher selves to our teacher selves. The two tales, while limited in scope, nevertheless showcase the authentic lived experiences of language teachers who sought to integrate EILinspired activities into ELT classrooms. Just as EIL has given voice to people from different linguistic backgrounds to communicate and understand one another, we have learnt that there is power in being able to hear others and to be heard. Previous research into EIL teaching practices have been largely limited to two research strategies of inquiry: case studies (e.g. Galloway 2017; Marlina 2018) and action research (e.g. Galloway and Rose 2014, 2017; Vetterol, 2013). Our unconventional use of duoethnography (or joint autoethnographies) as a method of inquiry provides a promising avenue for teacherresearchers to explore their own practices in relation to 'the Other' and to share these experiences within a wider professional community. Whether it is a success story or a cautionary account, recognising the pedagogical value of others' experiences is one of the most prominent takeaways of this tale of two.

\section{References}

Adamson J, Muller T (2017) Joint autoethnography of teacher experience in the academy: exploring methods for collaborative inquiry. International Journal of Research \& Method in Education. DOI: 10.1080/1743727X.2017.1279139

Baker W (2012) Using e-learning to develop intercultural awareness in ELT: a critical examination in a Thai higher education setting. ELT Research Papers 12(3). British Council.

Bayyurt Y, Sifakis N (2015) Developing an ELF-aware pedagogy: Insights from a selfeducation programme. In: Vettorel P (ed.) New Frontiers in Teaching and Learning English. Newcastle upon Tyne: Cambridge Scholars Publishing, pp.55-76.

Bayyurt Y, Sifakis N (2017) Foundations of an EIL-Aware Teacher Education. In: Matsuda A (ed.) Preparing Teachers to Teach English as An International Language. Bristol: Multilingual Matters, pp. 3-18. 
Borg S (2015) Teacher cognition and language education: Research and practice. London: Bloomsbury.

Breault RA (2016) Emerging issues in duoethnography. International Journal of Qualitative Studies in Education 29(6): 777-794.

Burhan-Horasanli E, Ortaçtepe D (2016) Reflective practice-oriented online discussions: A study on EFL teachers' reflection-on, in and for-action. Teaching and Teacher Education, 59: 372-382.

Ellis C, Bochner AP (2000) Autoethnography, personal narrative, reflexivity: Researcher as subject. In: Denzin NK, Lincoln YS (eds.) The Sage handbook of qualitative research. Thousand Oaks: Sage, pp.733-768.

Galloway N (2017) Global Englishes and Change in English Language Teaching: Attitudes and Impact. Abingdon: Routledge.

Galloway N, Rose H (2014) Using listening journals to raise awareness of Global Englishes in ELT. ELT Journal 68(4): 386-396.

Galloway N, Rose H (2015) Introducing Global Englishes. Abingdon: Routledge.

Galloway N, Rose H (2017) Raising awareness of Global Englishes in the ELT classroom. ELT Journal 72(1). Epub ahead of print 9 March 2017. DOI: 10.1093/elt/ccx010.

Lowe RJ, Kiczkowiak M (2016) Native-speakerism and the complexity of personal experience: A duoethnographic study. Cogent Education, 3(1): 1264171.

Marlina R (2017) Practices of Teaching Englishes for International Communication. In: Matsuda A (ed.) Preparing Teachers to Teach English as An International Language. Bristol: Multilingual Matters, pp.101-114.

Marlina R (2018) Teaching English as an International Language Implementing, Reviewing, and Re-Envisioning World Englishes in Language Education. Abingdon: Routledge.

McKay SL (2012) Teaching materials for English as an international language. In: Matsuda, A (ed) Principles and practices of teaching English as an international language. Bristol: Multilingual Matters, pp.70-83.

Matsuda A (2017) Introduction. In: Matsuda A (ed.)Preparing Teachers to Teach English as an International Language. Bristol: Multilingual Matters, pp.3-18.

Mora RA, Golovátina-Mora P (2017) A New Model for Reflexivity and Advocacy for Master'sLevel EIL In-Service Programs in Colombia: The Notion of 'Learning and Teaching Processes in Second Languages. In: Matsuda A (ed.) Preparing Teachers to Teach English as An International Language. Bristol: Multilingual Matters, pp.35-50

Norris J (2017) Duoethnography. In: Given LM (ed.) The SAGE encyclopedia of qualitative research methods. Thousand Oaks: Sage, pp.233-236.

Norris J, Sawyer R (2012) Toward a dialogic method. In: Norris J, Sawyer R \& Lund D (eds.) Duoethnography: Dialogic methods for social, health, and educational research. Walnut Creek, CA: Left Coast Press, pp.9-40. 
Paltridge B (2014) What motivates applied linguistics research? AlLA Review, 27(1): 98-104.

Rose R (2017) A Global Approach to English Language Teaching: Integrating an International Perspective into a Teaching Methods Course. In: Matsuda A (ed.) Preparing Teachers to Teach English as An International Language. Bristol: Multilingual Matters, pp.171-182.

Rose R, Galloway N (2017) Debating Standard Language Ideology in the Classroom: Using the 'Speak Good English Movement' to Raise Awareness of Global Englishes. RELC Journal. Epub ahead of print 6 January 2017. DOI: 10.1177/0033688216684281.

Selvi AF (2017) Preparing Teachers to Teach English as an International Language: Reflections from Northern Cyprus. In: Matsuda A (ed.) Preparing Teachers to Teach English as An International Language. Bristol: Multilingual Matters, pp.115-132.

Sung MCC (2017) Exploring language identities in English as a lingua franca communication: experiences of bilingual university students in Hong Kong. International Journal of Bilingual Education and Bilingualism, Epub ahead of print 26 July 2017. DOI: 10.1080/13670050.2017.1347138

Uzum B, Petrón M \& Berg H (2014) Pre-service teachers' first foray into the ESL Classroom: Reflective practice in a service learning project. TESL-EJ, 18(3): 1-15.

Van Manen M (1991) The tact of teaching: The meaning of pedagogical thoughtfulness. Albany, NY: SUNY Press.

Vettorel P (2013) ELF in international school exchanges: Stepping into the role of ELF users. Journal of English as a Lingua Franca, 2(1): 147-173.

Young TJ, Walsh S (2010) Which English? Whose English? An investigation of 'non-native' teachers' beliefs about target varieties. Language, Culture and Curriculum 23(2): 123137.

Zacharias NT (2017) Practicing EIL Pedagogy in a Microteaching Class. In: Matsuda A (ed.) Preparing Teachers to Teach English as An International Language. Bristol: Multilingual Matters, pp. 159-170. 